\title{
PERAN PENYULUH PERTANIAN DALAM MENDUKUNG KETAHANAN PANGAN PADA MASA PANDEMI COVID-19 DI KOTA TARAKAN
}

\author{
Zulhafandi $^{1}$, Ahmad Mubarak ${ }^{1}$ \\ ${ }^{1}$ Jurusan Agribisnis, Fakultas Pertanian, Universitas Borneo Tarakan \\ E-Mail: zulhafandi90@borneo.ac.id
}

Diterima : 11 September 2021

Disetujui : 21 September 2021

\begin{abstract}
Extension agents are promoters in influencing the innovation adoption process before the innovation is adopted by the community. In addition, extension workers are able to build farmer skills, strengthen farmer institutions, and increase partnerships with the government and other agribusiness actors in supporting food security. Among the roles of the extension agent are as an advisor to the organizer, technical assistant and as a liaison. North Kalimantan is a province that directly borders with neighboring countries forcing the government to be aware of the spread of this epidemic by implementing all the appeals from the central government, including several cities/districts that have implemented PSBB. This condition is clearly not profitable for the community, especially farmers, fishermen and ranchers who have difficulty in meeting the needs of themselves and their families. The purpose of this study was to describe the role of agricultural extension workers in supporting food security during the Covid-19 pandemic in Tarakan City. This study used descriptive qualitative method. The data collection technique was carried out by in-depth observation, data analysis began by examining all the data collected through in-depth interviews with key informants. The technique of checking the validity of the data (data validity) in this study is the triangulation technique. Based on the analysis of the role of agricultural instructors, it was found that there were obstacles or obstacles in carrying out extension activities and implementing the role of extension workers due to the limited intensity of face-to-face meetings with fostered farmers. Of the four roles of agricultural instructors, extension workers have more roles in the category as advisors and technical assistance in agricultural cultivation, but the role as organizer is not optimal because it can be seen from the managerial and administrative abilities of farmers who have not been good, besides that the role as a liaison has also not worked well. this can be seen from the lack of facilitation of farmers with financial institutions and marketing institutions.
\end{abstract}

Key words: The Role of Extension, Food Security, Covid-19

\begin{abstract}
ABSTRAK
Penyuluh merupakan promotor dalam mempengaruhi proses adopsi inovasi sebelum inovasi diadopsi oleh masyarakat. Selain itu, penyuluh mampu membangun keterampilan petani, memperkuat kelembagaan petani, serta meningkatkan kemitraan dengan pemerintah dan pelaku agribisnis lainnya dalam mendukung ketahanan pangan. Diantara peran penyuluh adalah sebagai penasehat organisator, pendamping teknis dan sebagai penghubung. Kalimantan Utara merupakan Provinsi yang berbatasan langsung dengan Negara tetangga memaksa pemerintahnya mewaspadai penyebaran wabah ini dengan menerapkan segala himbauan dari pemerintah pusat termasuk beberapa kota/kabupaten yang telah menerapkan PSBB. Kondisi ini jelas tidak menguntungkan bagi masyarakat terutama petani, nelayan dan peternak yang kesulitan dalam memenuhi kebutuhan diri dan keluarganya. Tujuan dari penelitian ini adalah mendeskripsikan peran Penyuluh Pertanian dalam mendukung Ketahanan Pangan Pada Masa Pandemi Covid-19 Di Kota Tarakan. Penelitian ini menggunakan metode deskriptif kualitatif. Teknik pengumpulan data dilakukan dengan observasi mendalam, analisis data dimulai dengan menelaah seluruh data yang dihimpun melalui wawancara mendalam dengan key informan. Teknik pemeriksaan keabsahan data (validitas data) dalam penelitian ini adalah teknik triangulasi. Berdasarkan analisis peran penyuluh pertanian ditemukan terdapat hambatan atau kendala dalam melaksanakan kegiatan penyuluhan dan pelaksanaan peran penyuluh dikarenakan terbatasnya intensitas pertemuan tatap muka dengan petani binaan. Dari ke empat peran penyuluh pertanian, Penyuluh lebih berperan dalam kategori sebagai penasehat dan pendampingan teknis budidaya pertanian, namun untuk peran sebagai organisator belum optimal karena terlihat dari kemampuan manajerial dan administrasi petani yang belum baik, selain itu peran sebagai penghubung juga belum berjalan dengan baik, hal ini terlihat dari belum terfasilitasinya petani dengan lembaga pembiayaan dan lembaga pemasaran.
\end{abstract}

Kata kunci: Peran Penyuluh, Ketahanan Pangan, Covid-19 


\section{PENDAHULUAN}

Penyuluhan pertanian memegang peranan yang sangat penting sebagai ujung tombak pembangunan di Indonesia. Beberapa pakar penyuluhan percaya bahwa dengan penyuluhan akan dapat meningkatkan sumberdaya manusia dan kapasitas sosial dalam mewujudkan masyarakat yang mandiri. Pada dasarnya penyuluhan merupakan proses pembelajaran/pendidikan dimana yang menjadi penerima manfaat adalah para petani, peternak, dan nelayan yang harus mengalami perubahan perilaku mulai dari aspek kognitif, afektif dan psikomotoriknya. Berdasarkan Undang-Undang No.16 Tahun 2006, Penyuluhan merupakan proses pembelajaran bagi pelaku utama serta pelaku usaha agar mereka mau dan mampu menolong dan mengorganisasikan dirinya dalam mengakses informasi pasar, teknologi, permodalan, dan sumberdaya lainnya, sebagai upaya untuk meningkatkan produktivitas, efisiensi usaha, pendapatan dan kesejahteraannya serta meningkatkan kesadaran dalam pelestarian fungsi lingkungan hidup (UU-RI No 16, 2006). Lohr dan Timothy dalam (Zulhafandi, 2019) mengatakan dari beberapa survey yang dilakukan peranan penyuluhan pertanian sangat penting dalam mempromosikan program-program inovatif kepada masyarakat selaku penerima manfaat dari program penyuluhan tersebut.

Penyuluh merupakan promotor dalam mempengaruhi proses adopsi inovasi sebelum inovasi diadopsi oleh masyarakat. Selain itu, penyuluh mampu membangun keterampilan petani, memperkuat kelembagaan petani, serta meningkatkan kemitraan dengan pemerintah dan pelaku agribisnis lainnya. Diantara peran penyuluh adalah : Pertama, peran sebagai penasehat yaitu penyuluh harus mampu memberikan bimbingan atau nasehat serta memotivasi petani dalam meningkatkan kapasitas dirinya; Kedua, peran sebagai organisator yaitu penyuluh memfasilitasi penerapan usahatani melalui penguatan kapasitas kelompok-kelompok tani; Ketiga, peran sebagai pendamping teknis yaitu penyuluh harus memiliki pengetahuan dan keterampilan teknis budidaya; dan Keempat, peran sebagai penghubung yaitu penyuluh harus memiliki kemampuan dalam membangun kerjasama dengan pihak luar seperti lembaga penelitian, lembaga pemasaran dan lembaga lainnya (Suhardiyono, 1992)

Kinerja penyuluh pertanian dipengaruhi oleh sejumlah faktor, yaitu karakteristik, psikologis dan organisasi penyuluh. Karakteristik penyuluh diklasifikasikan dalam kemampuan dan keterampilan, latar belakang pribadi dan demografis. Psikologis penyuluh dirumuskan dalam persepsi, sikap, kepribadian, belajar dan motivasi. Organisasi penyuluh dikelompokkan dalam sumber daya, kepemimpinan, imbalan, struktur dan desain pekerjaan.

Di tengah pandemi COVID-19, segala aspek kehidupan cenderung mengarah pada situasi normal baru. Himbauan pemerintah kepada masyarakat untuk melakukan pekerjaan dari rumah (working from home) dan menjaga jarak secara fisik (social/physical distancing) serta kebijakan beberapa pemerintah daerah yang mengimplementasikan karantina wilayah secara parsial dan melakukan pembatasan kegiatan di keramaian, telah membuat perubahan situasi yang baru di hampir semua aspek kehidupan, termasuk perubahan pola rantai pasok pangan. Sistem atau pola kerja di sektor pangan memang tampaknya berubah sangat signifikan di tengah pandemi COVID-19 ini, kondisi ini dikhwawatirkan akan mengganggu ketahan pangan yang ada di Indonesia, termasuk di Kota Tarakan yang merupakan daerah berpenduduk terbesar di Kalimantan Utara musti dapat menjaga ketersedian pangan dalam memenuhi kebutuhan masyarakat dimasa pandemi.

Ketahanan pangan tidak lepas dari UU No. 18/2012 tentang Pangan. Disebutkan dalam UU tersebut bahwa Ketahanan Pangan adalah "kondisi terpenuhinya Pangan bagi negara sampai dengan perseorangan, yang tercermin dari tersedianya pangan yang cukup, baik jumlah maupun mutunya, aman, beragam, bergizi, merata, dan terjangkau serta tidak bertentangan dengan agama, keyakinan, dan budaya masyarakat, untuk dapat hidup sehat, aktif, dan produktif secara berkelanjutan".

Di tengah pandemi COVID-19, terjadi penyesuaian yang cenderung bersifat masif. Hampir seluruh negara di dunia berusaha untuk memenuhi kebutuhan pangan domestiknya sendiri karena jalur perdagangan internasional terganggu semenjak wabah Covid-19 mulai menyebar. Produksi dalam negeri menjadi tumpuan utama bagi setiap negara saat ini, termasuk Indonesia. Untuk bisa menjalankan kegiatan pertanian yang optimal petani membutuhkan fasilitasi oleh penyuluh yang menjadi ujung tombak dalam menjaga ketahanan pangan.

Saat ini kinerja penyuluh pertanian terganggu dengan adanya wabah virus yang diduga berasal dari hewan namun mengalami mutasi yang cepat sehingga mampu menginfeksi dan menyebar dari manusia ke manusia. Wabah ini pertama kali dilaporkan pada akhir desember 2019 dan hingga kini sudah terjadi di hamper seluruh Negara di 
dunia. Kasus ini pertama kali ditemukan di Wuhan, provinsi Hubei. Tiongkok. Pada tanggal 11 Februari 2019 lembaga kesehatan dunia World Health Organization (WHO) mengumumkan nama resmi kejadian ini dengan Coronavirus diease 2019 (Covid-19).

Kalimantan Utara merupakan Provinsi yang berbatasan langsung dengan Negara tetangga memaksa pemerintahnya mewaspadai penyebaran wabah ini dengan menerapkan segala himbauan dari pemerintah pusat termasuk beberapa kota/kabupaten yang telah menerapkan pembatasan sosial berskala besar (PSBB). Kondisi ini jelas tidak menguntungkan bagi masyarakat terutama petani, nelayan dan peternak yang kesulitan dalam memenuhi kebutuhan diri dan keluarganya. Ditambah lagi dengan penyuluh yang menjadi ujung tombak pembangunan pertanian, yang membantu, memfasilitasi petani dalam kegiatan usahataninya juga harus mengikuti himbauan dan aturan dari pemerintah. Sehingga interaksi penyuluh dan petani sangat terbatas dan mengganggu agenda penyuluhan yang sebelumnya sudah disusun penyuluh bersama petani.

Berdasarkan kondisi tersebut maka peneliti tertarik melakukan penelitian tentang Peran Penyuluh Pertanian Dalam Mendukung Ketahanan Pangan Pada Masa Pandemi Covid-19 Di Kota Tarakan. Tujuan dari penelitian ini adalah Mengetahui dan mendeskripsikan Peran Penyuluh Pertanian Dalam Mendukung Ketahanan Pangan Pada Masa Pandemi Covid-19 Di Kota Tarakan.

\section{BAHAN DAN METODE}

Penelitian ini menggunakan metode deskriptif dengan pendekatan kualitatif yaitu menggambarkan dan mengekplorasi dengan jelas bagaimana Peran Penyuluh Pertanian Dalam Mendukung Ketahanan Pangan Pada Masa Pandemi Covid-19 Di Kota Tarakan Dilihat dari pendekatan ini, maka peneliti akan melakukan wawancara terbuka, berusaha memahami fenomena, fakta serta kejadian-kejadian yang ada untuk kemudian akan ditarik kesimpulan. Peneliti akan memaparkan keadaan yang sebenarnya ditemukan dilapangan berdasarkan hasil pengamatan, kemudian akan dianalisis sehingga nantinya akan diambil kesimpulan berdasarkan masalah penelitian. Informan dalam penelitian ini adalah Penyuluh dan Petani yang terlibat dalam kegiatan penyuluhan khususnya tanaman pangan. Informan dipilih dengan metode Snowball dengan memilih, mengidentifikasi informan yang dapat menjawab tujuan penelitian sampai data jenuh.
Dalam penelitian kualitatif tidak menggunakan "variabel" tetapi menggunakan istilah "topik data" (Sugiyono, 2012). Maka, topik data yang diambil dalam untuk tujuan pertama adalah Menggambarkan kegiatan penyuluhan ketahanan pangan dimasa pandemi seperti materi penyuluhan, media penyuluhan dan metode penyuluhan. Tujuan penelitian yang kedua adalah untuk mendalami Peran Penyuluh Pertanian Dalam Mendukung Ketahanan Pangan Pada Masa Pandemi Covid-19 Di Kota Tarakan. Data utama adalah pelaksanaan peran penyuluh menurut Suhardiyono (1992) yaitu : Pertama, peran sebagai penasehat, Kedua, peran sebagai organisator, Ketiga, peran sebagai pendamping teknis, Keempat, peran sebagai penghubung.

Teknik pengumpulan data dalam pendekatan kualitatif dilakukan dengan Observasi mendalam. Untuk mendapatkan data yang mendalam, Peneliti mengikuti setiap aktivitas penyuluh dan petani agar mendapatkan informasi yang mendalam, Wawancara dengan berpedoman pada $5 \mathrm{~W}+1 \mathrm{H}$ (What, Who, When, Where, Why dan How) dan studi kepustakaan

Analisis data dimulai dengan menelaah seluruh data yang dihimpun melalui wawancara dan observasi lapangan maupun dokumen resmi dari beberapa instansi terkait dengan penelitian. Setelah ditelaah dan dipelajari kemudian digenerasikan ke dalam suatu kesimpulan yang bersifat umum yang didasarkan atas fakta-fakta empiris. Teknik pemeriksaan keabsahan data (validitas data) dalam penelitian ini adalah teknik triangulasi. Teknik triangulasi menurut Sugiyono (2012) menyatakan bahwa teknik triangulasi merupakan teknik pengumpulan data data dan sumber yang telah ada. Bila penelitian melakukan pengumpulan data dengan triangulasi, maka sebenarnya peneliti mengumpulkan data yang sekaligus menguji kredibilitas data, yaitu mengecek kredibilitas data dengan berbagai teknik pengumpulan data dan berbagai sumber data.

\section{HASIL DAN PEMBAHASAN}

\section{Karakteristik Kota Tarakan dan Penyuluh}

Tarakan merupakan salah satu Kota yang ada di Provinsi Kalimantan Utara. Luas wilayah Kota Tarakan adalah 657,33 km2 dengan daratan seluas $250,80 \mathrm{~km}^{2}$ dan lautan seluas $406,53 \mathrm{~km}^{2}$. Akhir tahun 2017, wilayah administrasi Kota Tarakan terdiri dari 4 Kecamatan, dengan lu as daratan masing-masing kecamatan,yakni dapat dilihat pada tabel 3 dibawah ini: 
Tabel 1. Luas Wilayah Menurut Kecamatan Di Kota Tarakan

\begin{tabular}{ll}
\hline Kecamatan & Luas Wilayah $\left(\mathbf{K m}^{\mathbf{2}}\right)$ \\
\hline Tarakan Timur & 58,01 \\
Tarakan Tengah & 55,54 \\
Tarakan Barat & 27,89 \\
Tarakan Utara & 109,36 \\
\hline Jumlah & 250,8 \\
\hline \multicolumn{2}{l}{ Sumber: BPS Dalam Angka 2019 }
\end{tabular}

Penyuluh pertanian yang berada di Kota Tarakan berjumlah 11 orang. Yang terdiri dari 5 orang penyuluh PNS dan 6 orang penyuluh yang berstatus sebagai Tenaga harian lepas (THL TBPP). Berikut distribusi penyuluh berdasarkan usia :

Tabel 2. Distribusi Penyuluh berdasarkan usia

\begin{tabular}{cll}
\hline Usia & $\begin{array}{c}\text { Jumlah } \\
\text { (Orang) }\end{array}$ & $\begin{array}{c}\text { Persentase } \\
(\%)\end{array}$ \\
\hline $21-27$ & 1 & $9 \%$ \\
$28-34$ & 1 & $9 \%$ \\
$35-41$ & 6 & $55 \%$ \\
$42-48$ & 2 & $18 \%$ \\
$49-55$ & 1 & $9 \%$ \\
\hline Jumlah & 11 & $100 \%$ \\
\hline Sumber : Olah data Primer 2020
\end{tabular}

Wilayah kerja penyuluh pertanian dan perikanan yang ada di Kota Tarakan termasuk dalam 4 kecamatan yaitu, kecamatan Tarakan Timur, Tarakan Tengah, Tarakan Barat dan Tarakan Utara, dan wilayah kerja di 20 (dua puluh) kelurahan yang ada di Kota Tarakan yaitu: Kelurahan Lingkas Ujung, Kelurahan Gunung Lingkas, Kelurahan Pantai Amal, Kelurahan Kampung Empat, Kelurahan Kampung Enam, Kelurahan Mamburungan, Kelurahan Mamburungan Timur, Kelurahan Selumit, Kelurahan Selumit Pantai, Kelurahan Sebengkok, Kelurahan Pamusian, Kelurahan Kampung 1/SKIP, Kelurahan Karang Anyar, Kelurahan Karang Anyar Pantai, Kelurahan Karang Rejo, Kelurahan Karang Balik, Kelurahan Karang Harapan, Kelurahan Juata Kerikil, Kelurahan Juata Permai, dan Kelurahan Juata Laut.

Berkaitan dengan status pendidikan penyuluh didapatkan bahwa 10 Penyuluh memiliki pendidikan S1/D4, sedangkan 1 orang memiliki pendidikan S2 dan secara umum Penyuluh tersebut memiliki pengalaman kerja sebagai penyuluh pertanian selama 1-10 tahun. Selengkapnya dapat dilihat pada tabel 3 dan 4 .

Tabel 3. Tingkatan Pendidikan Penyuluh

\begin{tabular}{ccc}
\hline $\begin{array}{c}\text { Tingkat } \\
\text { Pendidikan }\end{array}$ & $\begin{array}{c}\text { Jumlah } \\
\text { (Orang) }\end{array}$ & $\begin{array}{c}\text { Persentas } \\
\text { e (\%) }\end{array}$ \\
\hline S2 & 1 & $9 \%$ \\
S1 & 9 & $82 \%$ \\
D IV & 1 & $9 \%$ \\
\hline Jumlah & 11 & $100 \%$ \\
\hline \multicolumn{2}{r}{ Sumber : Olah data Primer 2020 }
\end{tabular}

Tabel 4. Penyuluh berdasarkan pengalaman kerja

\begin{tabular}{lcl}
\hline Tahun & $\begin{array}{c}\text { Jumlah } \\
\text { (Orang) }\end{array}$ & Persentase (\%) \\
\hline $1-5$ & 4 & $36 \%$ \\
$6-10$ & 5 & $45 \%$ \\
$11-15$ & - & - \\
$16-20$ & 1 & $9 \%$ \\
$21-25$ & 1 & $9 \%$ \\
\hline Jumlah & 11 & $100 \%$ \\
\hline \multicolumn{2}{l}{ Sumber : Olah data Primer 2020 }
\end{tabular}

Peran Penyuluh Pertanian dalam mendukung Ketahanan Pangan di Kota Tarakan

1. Peran Penyuluh sebagai penasehat

Kondisi pandemi covid 19 yang masih berlanjut membuat peran $\mathrm{p}$ [enyuluh sebagai penasehat petani mengalami penurunan. Hal ini disebabkan karena intensitas pertemuan tatap muka dalam kegiatan penyuluhan dan kunjungan lapangan menjadi terbatas. Penyuluh Pertanian di Kota Tarakan tetap melaksanakan fungsi sebagai penasehat ini dengan menggunakan media komunikasi lain seperti WhatsApp dan Handphone dengan menghubungi petani-petani binaan. Selain itu peran penasehat juga dilakukan dengan mendatangi langsung petani ke lahannya dengan tetap memperhatikan protokol kesehatan. Namun ketika peneliti mewawancarai beberapa petani terkait peran ini, beberapa petani mengungkapkan penurunan intensitas kunjungan lapangan dan pertemuan penyuluh dengan petani, kondisi ini membuat petani harus menyelesaikan permasalahannya sendiri dilapangan tanpa fasilitasi Penyuluh

\section{Peran Penyuluh sebagai Organisator}

Peran sebagai Organisator berkaitan dengan bagaimana seorang Penyuluh mengelola kelompok tani binaannya menjadi lebih responsif, lebih mandiri dan memiliki daya saing yang tinggi. Kriteria Penyuluh yang berperan sebagai 
Organisator adalah Menumbuhkan kelompok tani, Menumbuhkan kemampuan administrasi dan manajemen kelompok tani, Mampu meningkatkan kualitas kelompok tani dari yang mula menjadi madya dan selanjutnya menjadi kelompok tani utama (Zulhafandi, 2019). Berdasarkan wawancara mendalam dan observasi yang dilakukan terhadap peranan PPL sebagai organisator adalah membantu kegiatan pendampingan pertemuan kelompok tani, memfasilitasi penyusunan RDK (Rencana Definitif Kelompok) dan RDKK (Rencana Definitif Kebutuhan Kelompok), memfasilitasi pembentukan kelompok-kelompok tani baru. Faqih (2013) menyebutkan indikator yang dapat menilai kinerja PPL terhadap dinamika kelompok tani adalah (a) tujuan kelompok, (b) struktur kelompok, (c) fungsi kelompok, (d) menggembangkan dan memelihara kelompok,. (e) kesatuan kelompok (f) suasana kelompok dan (g) tekanan/desakan kelompok(Faqih Ahmad, 2013).

Salah satu fungsi penyuluhan ialah bagaimana penyuluh tidak hanya mampu menumbuhkan kelompok-kelompok tani, melainkan juga dapat membangun struktur kelembagaan agribisnis dalam upaya penguatan sistem agribisnis, sehingga diharapkan dengan terbangunnya struktur kelembagaan petani yang kuat maka keberdayaan petani dalam sistem agribisnis juga semakin kuat. Sutrisno et al., (2020) mengungkapkan kelembagaan social dan petani yang lemah akan menghambat berjalannnya sistem agribisnis yang baik, ketika kelompok tani tidak memiliki kapasitas yang baik maka petani juga tidak akan mampu mengakses sumberdaya yang ada seperti pasar, koperasi, mitra dan lain sebagainya (Sutrisno et al., 2020)

\section{Peran Penyuluh sebagai Pendamping teknis}

Peran penyuluh sebagai pendamping teknis berkaitann dengan kemampuan penyuluh dalam memfasilitasi petani dalam kegiatan budidaya tanaman. Berdasarkan observasi mendalam dilapangan dengan penyuluh dan petani didapatkan peran penyuluh dalam pendampingan teknis budidaya tanaman padi dan jagung sudah berjalan dengan baik. Penyuluh member pembelajaran kepada petani tentang pengolahan tanah, pemilihan benih yang baik, serta teknik penenaman padi dan jagung yang baik dan benar. Mardikanto (2009) mengungkapkan saat ini penyuluh dituntut menyampaikan materi penyuluhan tidak hanya materi tentang teknis budidaya suatu komuditas tertentu tetapi, namun harus memperhatikan inovasi-inovasi lokal berupa keunggulan lokal, pengalaman masyarakat (petani) setempat, nilainilai tradisi dan kearifan lokal (endegenuous technology) yang selain telah teruji oleh waktu, seringkali memiliki banyak keunggulan disbanding dengan inovasi yang berasal dari luar (Mardikanto, 2009).

\section{Peran Penyuluh sebagai penghubung}

Peranan penyuluh Pertanian sebagai penghubung adalah bagaimana PPL membatu petani dalam menjalin hubungan dengan stakeholder diluar pelaku utama yang mampu meningkatkan pendapatan dan kesejahteraan petani. Stakeholder diluar pelaku utama yang dimaksud seperti : 1) Penyuluh membantu menghubungkan petani dengan lembaga keuangan agar petani tidak kesulitan dalam mendapatkan modal/pembiayaan dalam kegiatan usahataninya. Dalam kaitan ini temuan dilapangan belum adanya fasilitasi Penyuluh dalam menghubungkan petani dengan lembaga keuanga. Petani masih menggunakan modal pribadi untuk kegiatan usahataninya, lembaga pembiayaan yang saat ini membantu petani dilapangan hanya lembaga keuangan informal seperti keluarga, teman, dan seseorang yang menawarkan pinjaman dengan catatan petani nanti menjual hasil panen nya kepada orang tersebut. Sedangkan lembaga pembiayaan formal belum terfasilitasi oleh penyuluh. Ketika ini ditanyakan kepada penyuluh, maka penyuluh tidak menyangkal hal itu, Penyuluh beralasan lembaga pembiayaan forman biasanya mensyaraktkan adanya jaminan dalam kegiatan pembiayaan yang disalurkan, sementara lahanlahan yang dikelola oleh Petani kebanyakan lahan orang lain sehingga tidak bisa dijadikan jaminan.

Berkaitan dengan fasilitasi Penyuluh menghubungkan petani dengan Pelaku usaha dan pemasaran belum terlihat maksimal karena temuan dilapangan didapatkan bahwa petani masih kesulitan dalam memasarkan hasil usahataninya ditambah lagi dengan pandemi ini menurunkan daya beli masyarakat terhadap beberapa komuditas pertanian. Saat ini, petani memasarkan hasil usahataninya secara mandiri dengan menjual ke pengumpul, atau langsung menjual ke pasar tradisional serta menjual langsung kepada masyarakat seperti pada jagung manis sebagian petani menjual langsung kepada masyarakat sehingga harga jualnya relatif lebih tinggi dibandingkan menjual kepada pengumpul. Mosher (1987) yang menjelaskan lima syarat pokok dan lima syarat pelancar pembangunan pertanian, tanpa salah satu dari masing-masing syarat tersebut maka tidak akan terjadi pembangunan pertanian. Lima syarat pokok untuk membangun pertanian menurut Mosher tersebut adalah: (1) pasar untuk hasil-hasil 
pertanian, (2) teknologi yang selalu berubah, (3) tersedianya sarana produksi dan perlatan secara lokal, (4) perangsang produksi bagi petani, dan (5) pengangkutan atau transportasi (Mosher AT, 1987)

\section{KESIMPULAN}

Berdasarkan penelitian yang telah dilakukan tentang peran penyuluh dalam pertanian dalam mendukung Ketahanan Pangan dimasa pandemi Covid 19 maka didapatkan bahwa ada 11 orang penyuluh yang bertugas di Kota Tarakan yang tersebar pada 4 kecamatan. Dari 11 orang penyuluh tersebut, sebanyak 10 orang memiliki pendidikan S1 dan D4 dan 1 orang berpendidikan S2.

Berdasarkan analisis peran penyuluh pertanian ditemukan terdapat hambatan atau kendala dalam melaksanakan kegiatan penyuluhan dan pelaksanaan peran penyuluh dikarenakan terbatasnya intensitas pertemuan tatap muka dengan petani binaan. Dari keempat peran penyuluh pertanian, Penyuluh lebih berperan dalam kategori sebagai penasehat dan pendampingan teknis budidaya pertanian, namun untuk peran sebagai organisator belum optimal karena terlihat dari kemampuan manajerial dan administrasi petani yang belum baik, selain itu peran sebagai penghubung juga belum berjalan dengan baik, hal ini terlihat dari belum terfasilitasinya petani dengan lembaga pembiayaan dan lembaga pemasaran

\section{UCAPAN TERIMA KASIH}

Ucapan terima kasih disampaikan kepada Universitas Borneo Tarakan yang telah membantu memberikan bantuan pendanaan melalui DIPA UBT, Terimakasih juga kepada Dekan dan jajaan pimpinan di Fakultas Pertanian, rekan-rekan dosen dan mahasiswa yang telah membantu dalam proses penelitian

\section{DAFTAR PUSTAKA}

Faqih Ahmad (2013) Peranan Penyuluh Pertanian Lapangan (Ppl) Dalam Pemberdayaan Kelompok Tani (Studi Kasus Pada Kelompok Tani Tanaman Pangan Di Pesisir Pantai Kabupaten Cirebon). [disertasi].Universitas Sebelas Maret. Surakarta.

Mardikanto, T. 2009. (2009) Sistem Penyuluhan Pertanian. Surakarta: UNS Press.

Mosher AT (1987) Menggerakkan dan Membangun Pertanian. jakarta: Penerbit CV Yosaguna.

Sugiyono (2012) Metode Penelitian Kuantitatif, Kualitatif dab $R \& D$. Bandung: Alfabeta.

Suhardiyono, L. 1992. (1992) Penyuluhan: Petunjuk Bagi Penyuluh Pertanian. Jakarta: Erlangga.

Sutrisno, A. et al. (2020) 'Structural model design of the role of institutions in the development of cayenne agribusiness systems', IOP Conference Series: Earth and Environmental Science, 473(1). doi: 10.1088/1755-1315/473/1/012015.

UU-RI No 16 (2006) 'Sistem Penyuluhan Pertanian, Perikanan, Dan Kehutanan', Undang Undang Republik Indonesia Nomor 16 Tahun 2006, 16, p. 39. doi: 10.1017/CBO9781107415324.004.

Zulhafandi (2019) 'Peran Penyuluh Dalam Memfasilitasi Penerapan Budidaya Padi Organik Di Kabupaten Padang Pariaman', In Seminar NasionalPenyuluhan, Komunikasi Pembangunan Dan Pemberdayaan Masyarakat (Semnas $P k p-P m)$. Padang: Program Pascasarjana Universitas Andalas. 